\title{
Ultra-depleted residual mantle peridotites in ophiolites from Papua New Guinea: Earth's most depleted melting residues
}

\author{
NATASHA BARRETT ${ }^{1,2}$, A. LYNTON JAQUES ${ }^{3}$, D. \\ GRAHAM PEARSON ${ }^{2}$, IGNACIO GONZÁLEZ-ÁLVAREZ ${ }^{4}$ \\ AND MICHAEL J. WALTER ${ }^{5}$ \\ ${ }^{1}$ University of Copenhagen \\ ${ }^{2}$ University of Alberta \\ ${ }^{3}$ Australian National University \\ ${ }^{4}$ Commonwealth Scientific and Industrial Research Organisation \\ (CSIRO) \\ ${ }^{5}$ Carnegie Institution for Science \\ Presenting Author: nbarrett@ualberta.ca
}

Tectonite peridotites from the Papuan Ultramafic Belt (PUB) and Marum ophiolites of Papua New Guinea (PNG) represent some of the most melt-depleted mantle peridotites on Earth ( 25 to $>40 \%$ partial melting of fertile peridotite). These peridotites are characterized by olivine Fo contents between $\mathrm{Fo}_{91.2}$ to $\mathrm{Fo}_{94.6}$, spinel $\mathrm{Cr} \#$ values between 0.71 to 0.95 , very low bulk-rock $\mathrm{Al}$ and $\mathrm{Ca}$ abundances $\left(0.03-0.35\right.$ wt. $\% \mathrm{Al}_{2} \mathrm{O}_{3} ; 0.03-0.25$ wt. \% $\mathrm{CaO}$ ), and high $\mathrm{Cr} / \mathrm{Al}$ ratios $(1.3-12.7)$. We re-examine the origin of these ultra-depleted mantle residues through new major-, trace element, highly siderophile element (HSE), and Os isotope data to better understand the timing and processes involved in the formation of such ultra-depleted mantle compositions.

The Marum harzburgites, while still considered "ultradepleted", are not as melt depleted as the PUB harzburgites and could have formed under near anhydrous conditions if produced at low pressures $(\leq 2 \mathrm{GPa})$ and high temperatures $(\sim 1250-1350$ $\left.{ }^{\circ} \mathrm{C}\right)$. The PUB harzburgites, however, require a water-fluxed melt environment to reach their extensive levels of melt depletion. These results point towards a multi-stage melt evolution. The first-stage melting most likely occurred during subduction initiation and production of fore-arc-basalt(FAB)-like lavas, while second-stage melting involved a water-fluxed environment resulting in the production of extremely depleted peridotite residues of the PUB and eruption of the overlying Cape Vogel boninite lavas.

HSEs in the PNG peridotites are characterized by very low Os, Ir and Pt abundances and do not reflect typical Ir-group to Ptgroup PGE fractionation observed in large degree melt residues, but rather reflect dissolution of PGE-rich phases. ${ }^{187} \mathrm{Os} /{ }^{188} \mathrm{Os}$ ratios reflect values within the range of modern convecting mantle, indicating that these very depleted compositions in the mantle section of the PNG ophiolites are not linked to ancient melt depletion events. 